\title{
Theories' Gap of international Technological Entrepreneurship Opportunities
}

\author{
Mohammad Amin Keshmiri Hagh ${ }^{1}$, Mohammad Hassan Mobaraki ${ }^{2}$, Jahangir Yadollahi Farsi ${ }^{2}$, Ali Mobini \\ Dehkordi $^{2}$ \\ ${ }^{1} \mathrm{PhD}$ Candidate in Entrepreneurship, Faculty of Entrepreneurship, University of Tehran, Tehran, Iran \\ ${ }^{2}$ Associate Professor, Faculty of Entrepreneurship, University Of Tehran, Tehran, Iran \\ Correspondence: Mohammad, Hassan Mobaraki, Associate Professor, Faculty of Entrepreneurship, University of \\ Tehran, Tehran, Iran
}

Received: February 7, 2018

Accepted: August 2, 2018

Online Published: August 27, 2018

doi:10.5539/ibr.v11n9p79

URL: https://doi.org/10.5539/ibr.v11n9p79

\begin{abstract}
Most scholars believe that for recognition and exploiting entrepreneurial opportunities the traditional models and theories of don't have the required efficiency in the technological and international contexts since the liner nature of these models aren't compatible with these situations and needs nonlinear models to identify and exploit these opportunities. Therefore, applying suitable and new strategies are inevitable to provide customers' requirements with uncertainties in the technological and international contexts. In this study, the theories about international technological entrepreneurship opportunities are discussed and the theoretical gaps were investigated. The review revealed that some questions are in this field that have not been regarded in the current theories and more studies should be conducted based on these topics to answer the theoretical gaps.
\end{abstract}

Keywords: technology entrepreneurship, international entrepreneurship, international technological entrepreneurial opportunities

\section{Introduction}

The exploitation of international entrepreneurship opportunities by technological SMEs can lead to their high growth (Peng \& Delios, 2006) And it's vital to them because small and medium-sized enterprises involved in international markets got dramatic improvements in their performance.(Baldwin \& Gu, 2003)

In the technological fields there are many evidences that show the pure uncertainty and these are a lot of technological solutions that fail even with high investments. An increasing number of studies on entrepreneurial opportunities have emerged on the entrepreneurship landscape in recent times(Busenitz, Plummer, Klotz, Shahzad, \& Rhoads, 2014)

Based on the trend analysis of Busenitz et al. (2014), research on entrepreneurial opportunities will continue to increase, and will, therefore, become the most important topic in the field of entrepreneurship.

There have been many request and asking the researchers to combine entrepreneurship studies with international entrepreneurship research so that create fundamental and theoretical bases related to the international opportunities(Chandra, Styles, \& Wilkinson, 2009; Mainela, Puhakka, \& Servais, 2014)

Getting value and competitive advantage from technological entrepreneurial opportunities emergence is one of the important factors for technological enterprises.so the creation theory has great position in the international technological enterprises. Entrepreneurial opportunities in the future couldn't be predicted with the present knowledge and information especially in the technological fields. Mostly the disruptive technologies cause that prediction of these opportunities impossible.

These types of international technological opportunities embrace uncertainty that was mentioned by (Knight, 1921) With fast changing technologies trends, most technological entrepreneurial opportunities are Schumpeterian and these can be seen as the opportunities that through creative destruction move markets towards disequilibrium when entrepreneurs invent new solutions (Schumpeter, 1934)

Creation theory tries to explain and investigate the entrepreneurial opportunities formation and their exploitation in the Knightian uncertainty of the entrepreneur.(S. A. Alvarez \& Barney, 2005) 
In the international technological contexts because of pure uncertainty, prediction is impossible and traditional models couldn't explain the international technological entrepreneurial opportunities emergence and exploitation and they don't have complete efficiency. With rapid technological inventions and changes, there has been great shift in the business paradigm and many international opportunities have been emerged and a lot of new international ventures created with high growth and high value creation for example, eBay 1.3 B \$, Facebook 33 B \$, WhatsApp 22 B \$(Alimadadi, Bengtson, \& Hadjikhani, 2018)

In this study international technological entrepreneurship opportunity concept have been addressed and the gap among present theories in this area have been discussed.

\section{International Entrepreneurship Opportunities}

International Entrepreneurship (IE) is inherently a cross-disciplinary research field that combines international business and entrepreneurship (Jones, Coviello, \& Tang, 2011; McDougall \& Oviatt, 2000).

Along the conceptual developments in its root theories, international opportunities have been set in the core of the research field(Mainela et al., 2014; Oviatt \& McDougall, 2005)

However, in International Entrepreneurship research, the international opportunity concept is used in very diverse ways, as a concept in the theoretical frameworks, as a variable in questionnaires or a topic in interview guides, and in conceptualizing and modelling research results.(Mainela, Puhakka, \& Wakkee, 2017)

There are many definitions of international opportunities. Casulli (2009) defines international entrepreneurial opportunities as " an opportunity to create value in organizations through a combination of innovative, proactive and risk-seeking behavior that crosses national borders" (p. 22) Or Ciravegna, Majano, and Zhan (2014) defines international entrepreneurial opportunities as "the first finalized contract for the sale of products to a client based in a foreign market where the firm had not previously operated" (p. 1084) Or according to the Ellis (2011) definition international entrepreneurial opportunities is "“'the chance to conduct exchange with new partners in new foreign markets" (p. 101).

Also there are other definitions that show other aspects of this concept for example Hurmerinta, Nummela, and Paavilainen-Mäntymäki (2015) defines international entrepreneurial opportunities as "the potential the decision-maker sees for exchanging goods and services in selected markets" (p.1084) Or according to the Mainela et al. (2014) definition international entrepreneurial opportunities as "a situation that both spans and integrates elements from multiple national contexts in which entrepreneurial action and interaction transform the manifestations of economic activity" (p. 120) Or Muzychenko and Liesch (2015) defines international entrepreneurial opportunities as " the likelihood of conducting exchange with new or existing partners, such as foreign intermediaries or foreign customers, in new international markets" (p.705) Indujeeva K Peiris, Michèle Akoorie, and Paresha Sinha (2015) mention the international entrepreneurial opportunities as the "a situation in which new goods and services are introduced across national borders through formation of means-ends relationships that delivers superior value! (p.196) “

And finally Zahra, Korri, and Yu (2005) define as "in an iterative process, where the entrepreneur revises her (his) concept several times" (p.139)

In international entrepreneurship, the identifying international entrepreneurship opportunities is an emerging concept and its importance has grown. Although there were several calls in different Entrepreneurship research journals about discussions related international opportunities( for example (ET \& P, (2014), Volume 29, Issue 2) it has not yet been provided a comprehensive theoretical framework for understanding the process related to the recognition and seizing the international opportunities. (Indujeeva K. Peiris, Michèle Akoorie, \& Paresha Sinha, 2015)

\section{Technological Entrepreneurship Opportunities}

According to the process of technology entrepreneurship is about" recognizing, creating, and exploiting opportunities, and combining the resources around a technological solution, Irrespective of the organizational context" (Bailetti, 2012; Ratinho, Harms, \& Walsh, 2015; Spiegel \& Marxt, 2011)

The technological solution opens up new possibilities, it allows the reduction of transactional costs(Williamson, 2005) and it has the ability to apply new technology product paradigm to provide a solution to a market gap(Ratinho et al., 2015)

Technology entrepreneurship differs from general entrepreneurship and it focuses on technological opportunities that require deep technological as well as managerial capabilities.(Prahalad \& Hamel, 2000; Walsh \& Linton, 2011) 
In other words, it requires a higher level of technical capabilities and management of a risky environment(Harms, Marinakis, \& Walsh, 2015)

Alternatively, it involves the same opportunity identification, organization, and execution found in any other form of entrepreneurship but around a focused technology and a business model that makes it unique.(Tripathi \& Brahma, 2018)

According to Antonic\&Pordan(2008) technological entrepreneurship (or its synonyms, i.e. entrepreneurship, techno-entrepreneurship, and tecnoentrepreneurship) consists of "a set of behaviours and actions that drive the market process (and also a strategy) which is based on identifying high potential, technology-intensive commercial opportunities, gathering/assembling resource and managing rapid growth and significant risk with the final aim to exploit those opportunities for value creation"(Antoncic \& Prodan, 2008)

also technological entrepreneurship has been defined as "the recognition or even the creation of potential business value of new discoveries and technologies, to the matching with existing and/or potential market needs, and finally the transformation of opportunities arising in commercial products, services and new businesses (Petti, 2009)

\section{The Emergence Process and Exploitation of Technological International Entrepreneurship Opportunities}

There are different approaches toward the international technological entrepreneurship opportunities emergence. the process approach is one of them.(Davidsson, 2005)

Davidsson (2005) mentions that there are some process models in the field related to the opportunity recognition and exploitation and he notes that given the fact that these process models are experimental so it is thought that applying these models is the context dependent. He also mentions this question that which one is the best process. By this question, two different entrepreneurial process models were introduced, the by Bhave (1994) and S. D. Sarasvathy (2001) models, arguing that most of the real-world processes are at the point between these two types of linear processes (Analytical and programmed) and emerging (creative and repetitive), and the superiority of one model to another depends on the proportion of the type of process and other key factors, i.e. the entrepreneur, the environment and the opportunity features or idea.(Jamali, Kazemi, Farsi, \& Dehkordi, 2018) Therefore, the entrepreneurial process in the proper sense, it presents a model with entrepreneurial elements. The important part of this model is that we could not see any direct relationship between process and performance, and, the process success depends on its fitness with the idea, opportunity and the context features and the entrepreneur (Davidsson, 2005)

Considering the appropriateness between the idea and the entrepreneur and context, the theoretical background and previous studies mention to the fact that entrepreneurs are searching the ideas that can use their own unique motivates, hobbies and competencies in them, which is fundamental in the resource based view. This appropriateness is compatible with the Impact Model (S. Sarasvathy, 2008), which starts with entrepreneurial resources. Also, the bricolage theory (Baker \& Nelson, 2005) focuses on the available resources use of by an entrepreneur.

Another approach related to the international technological entrepreneurship opportunities emergence is the resource based theory.

S. A. Alvarez, \& Busenitz, L. W. (2001) emphasized applying the resource based approach in the entrepreneurship theory and investigated the relationship between resource based theory and entrepreneurship. They pointed to the heterogeneity as a common characteristic between two resource based theory and entrepreneurial theory. But in the resource based theory, the focal point is on the resource heterogeneity, but the focal point of the entrepreneurship theory is on heterogeneity in the thought and idea that there is the valuable resource that enables entrepreneurs to transform homogeneous resources into heterogeneous outputs and have a better choice than others. The main question in the application of resource-centered theory in entrepreneurship is that of the source of heterogeneous sources of entrepreneurship.(Jamali et al., 2018)

Available resources make asymmetry in the looking for the new source competition (Wernerfelt, 2011). This argument is accordance with the first type of path dependence, which was suggested by S. A. Alvarez and Barney (2007) and mentioned the explicitly in the theory of action because entrepreneurs responded to the questions "Who am I? What I know and who I know." And finally, the answer to the question" What can I do? in the theory of action, "(S. Sarasvathy, 2008)

Another important concept that has great effect on the international technological entrepreneurship opportunities is the uncertainty. The creation theory of international technological opportunities emphasize on the role 
uncertainty .so the outcomes of the exploitation of these type of opportunities are unclear and unpredictable.(S. A. Alvarez \& Barney, 2007)

According to this theory, two conceptualization of the international technological entrepreneurship could be found, first international technological entrepreneurship is considered as the output of the low level uncertainty understanding, and the second the international technological entrepreneurship is the output of the eagerness to bear the uncertainty (Bauer, Bell, Nelson, \& Calhoun, 2017)

The final theory that is fundamental in the entrepreneurial opportunities emergence especially in the technological and international context is the institutional theory. institutions are described as human structures that make social, economic, and political norms and values and human beings relations (North, 1990)

Institutional theory in the international entrepreneurship researches especially in the technological contexts has the position in the following areas: the first research area investigates the effects of institutional circumstances on entrepreneurship, in which the developed institutional contexts develops entrepreneurship and improves the appropriateness of the institutional environment for entrepreneurial activities. The second part is related to the relationship between legitimacy and entrepreneurial activities and focus on how entrepreneurs are seeking legitimacy for their businesses. In fact, entrepreneurs have to form the desired actions and structures according to the social system of their context because otherwise they will be isolated by avoiding from accepted social values and finally is the institutional entrepreneurship. The concept of institutional entrepreneurship answers the question of how new institutions are constructing and modifying. (Bruton, Ahlstrom, \& Li, 2010)

\section{Theoretical Gaps}

Exploitation of international entrepreneurship opportunities is a widespread phenomenon that has been studied in the last few decades. It has been investigated from different theoretical perspectives. Although ,entrepreneurial behaviors focusing on international entrepreneurship opportunities in International Entrepreneurship are Important, but the international opportunities are often expressed in an unspecified way, and the international entrepreneurship research suffers from little or no theoretical discussion and consistency of the concept of international entrepreneurship opportunities.(Mainela et al., 2014)

On the other hand exploitation of international entrepreneurship opportunities by technological SMEs can lead to their high growth (Peng \& Delios, 2006) and it's vital to them because these types of enterprises involved in international markets got dramatic improvements in their performance.(Baldwin \& Gu, 2003)

Technological entrepreneurship opportunities are one of the key elements in the Technological entrepreneurship and it has multiple dimensions and nature. With new technological changes and high value creation by technological enterprises, the technological entrepreneurship has gained so much attention and importance especially in the international levels.

Technological entrepreneurship opportunities are defined as the possibilities to create new products, which originate from the divergence of beliefs towards the future value of previously un-exploited technologies.(Petti \& Zhang, 2011)

Nowadays, there are many technological small and medium enterprises that grow internationally rapidly and exploit technological entrepreneurial opportunities internationally.

The stage models failed to explain why entrepreneurial firms enter international markets soon after their inception.(Peiris, 2014)

IE theorists argued that it is the unique entrepreneurial knowledge and capabilities that allow firms to identify and exploit opportunities in international markets(Autio, Sapienza, \& Almeida, 2000)

However, IE theory falls short in explaining how this knowledge and these capabilities contributed to opportunity identification and subsequent behavior of the firm.(Peiris, 2014)

There is little explanation about the process or the individuals required abilities to identify international entrepreneurship opportunities. (Andersson \& Evers, 2015)

Researchers in the field of International Entrepreneurship emphasize that there should be more research on how the international opportunities are recognized and exploited in the International context especially in technological fields. How to identify and exploit international technological opportunities and the capabilities needed for this process in technological International Small and Medium enterprises are the key research areas and questions that should be investigated .(Andersson \& Evers, 2015)

Although there are many researches are conducted based on the questions about how the entrepreneurship 
opportunities are discovered and exploited in international markets and what capabilities are required but the literature of international entrepreneurship research is still substantially lacking maturity .(Jones et al., 2011)

Another important research gaps that should be addressed in international entrepreneurship opportunities especially in technological fields is the transformation between opportunities under discovery theory and creation theory. Identifying the conditions and circumstance that these two types of opportunities transforms to each other requires more research.(S. A. Alvarez \& Barney, 2010)

The nature of technological entrepreneurship opportunities in the international context are complex and unpredictable and when there is the situation that both creation and discovery processes are conducted about international technological entrepreneurship opportunities, the decision making and the methods and tools that are used should be a dilemma.so these situations require more research to be investigated.(S. A. Alvarez, Barney, $\&$ Anderson, 2013)

\section{Discussion and Conclusion}

The exploitation of international entrepreneurship opportunities by technological small and medium-sized enterprises can lead to their high growth and it's vital to them because small and medium-sized enterprises involved in international markets got dramatic improvements in their performance. International technological entrepreneurship introduce new technological products or services in the international contexts and these types of entrepreneurs exploit entrepreneurial opportunities based on the technological changes in the international markets and because they create new technological products or services then create market for it these are based on the creation theory of the entrepreneurship. Based on these studies although the international technological entrepreneurship opportunities play an important role in these research areas but there are many issues that should be investigated.

\section{References}

Alimadadi, S., Bengtson, A., \& Hadjikhani, A. (2018). How does uncertainty impact opportunity development in internationalization? International Business Review, 27(1), 161-172. https://doi.org/10.1016/j.ibusrev.2017.06.002

Alvarez, S. A., \& Busenitz, L. W. (2001). The entrepreneurship of resource-based theory. Journal of Management, 6(27), 755-775. https://doi.org/10.1177/014920630102700609

Alvarez, S. A., \& Barney, J. B. (2005). How do entrepreneurs organize firms under conditions of uncertainty? Journal of management, 31(5), 776-793. https://doi.org/10.1177/0149206305279486

Alvarez, S. A., \& Barney, J. B. (2007). Discovery and creation: Alternative theories of entrepreneurial action. Strategic entrepreneurship journal, 1(1-2), 11-26. https://doi.org/10.1002/sej.4

Alvarez, S. A., \& Barney, J. B. (2010). Entrepreneurship and epistemology: The philosophical underpinnings of the study of entrepreneurial opportunities. Academy of Management annals, 4(1), 557-583. https://doi.org/10.5465/19416520.2010.495521

Alvarez, S. A., Barney, J. B., \& Anderson, P. (2013). Forming and exploiting opportunities: The implications of discovery and creation processes for entrepreneurial and organizational research. Organization Science, 24(1), 301-317. https://doi.org/10.1287/orsc.1110.0727

Andersson, S., \& Evers, N. (2015). International opportunity recognition in international new ventures-a dynamic managerial capabilities perspective. Journal of International Entrepreneurship, 13(3), 260-276. https://doi.org/10.1007/s10843-015-0149-5

Antoncic, B., \& Prodan, I. (2008). Alliances, corporate technological entrepreneurship and firm performance: Testing a model on manufacturing firms. Technovation, 28(5), 257-265. https://doi.org/10.1016/j.technovation.2007.07.005

Autio, E., Sapienza, H. J., \& Almeida, J. G. (2000). Effects of age at entry, knowledge intensity, and imitability on international growth. Academy of management Journal, 43(5), 909-924.

Bailetti, T. (2012). Technology entrepreneurship: overview, definition, and distinctive aspects. Technology Innovation Management Review, 2(2), 5. https://doi.org/10.22215/timreview/520

Baker, T., \& Nelson, R. E. (2005). Creating something from nothing: Resource construction through entrepreneurial bricolage. Administrative science quarterly, 50(3), 329-366. https://doi.org/10.2189/asqu.2005.50.3.329

Baldwin, J. R., \& Gu, W. (2003). Export - market participation and productivity performance in Canadian 
manufacturing. Canadian Journal of Economics/Revue canadienne d'économique, 36(3), 634-657. https://doi.org/10.1111/1540-5982.t01-2-00006

Bauer, D. M., Bell, K. P., Nelson, E. J., \& Calhoun, A. J. (2017). Managing small natural features: A synthesis of economic issues and emergent opportunities. Biological Conservation, 211, 80-87. https://doi.org/10.1016/j.biocon.2017.01.001

Bhave, M. P. (1994). A process model of entrepreneurial venture creation. Journal of business venturing, 9(3), 223-242. https://doi.org/10.1016/0883-9026(94)90031-0

Bruton, G. D., Ahlstrom, D., \& Li, H. L. (2010). Institutional theory and entrepreneurship: where are we now and where do we need to move in the future? Entrepreneurship theory and practice, 34(3), 421-440. https://doi.org/10.1111/j.1540-6520.2010.00390.x

Busenitz, L. W., Plummer, L. A., Klotz, A. C., Shahzad, A., \& Rhoads, K. (2014). Entrepreneurship research (1985-2009) and the emergence of opportunities. Entrepreneurship theory and practice, 38(5), 981-1000. https://doi.org/10.1111/etap. 12120

Casulli, L. (2009). Exploring opportunity creation in internationalizing SMEs: Evidence from Scottish firms. Internationalisation, entrepreneurship and the smaller firm: Evidence from around the world, 20-36. https://doi.org/10.4337/9781848447363.00010

Chandra, Y., Styles, C., \& Wilkinson, I. (2009). The recognition of first time international entrepreneurial opportunities: Evidence from firms in knowledge-based industries. International Marketing Review, 26(1), 30-61. https://doi.org/10.1108/02651330910933195

Ciravegna, L., Majano, S. B., \& Zhan, G. (2014). The inception of internationalization of small and medium enterprises: The role of activeness and networks. Journal of Business Research, 67(6), 1081-1089. https://doi.org/10.1016/j.jbusres.2013.06.002

Davidsson, P. (2005). The types and contextual fit of entrepreneurial processes. International Journal of Entrepreneurship Education, 2, 4,407-430.

Ellis, P. D. (2011). Social ties and international entrepreneurship: Opportunities and constraints affecting firm internationalization. Journal of international business studies, 42(1), 99-127. https://doi.org/10.1057/jibs.2010.20

Harms, R., Marinakis, Y., \& Walsh, S. T. (2015). Lean startup for materials ventures and other science-based ventures: under what conditions is it useful? Translational materials research, 2(3), 035001.

Hurmerinta, L., Nummela, N., \& Paavilainen-Mäntymäki, E. (2015). Opening and closing doors: The role of language in international opportunity recognition and exploitation. International business review, 24(6), 1082-1094. https://doi.org/10.1016/j.ibusrev.2015.04.010

Jamali, B., Kazemi, R. M., Farsi, J. Y., \& Dehkordi, A. M. (2018). The Study on the Theories' Gap of Technological Entrepreneurship Opportunities Emergence. International Business Research, 11(2), 79. https://doi.org/10.5539/ibr.v11n2p79

Jones, M. V., Coviello, N., \& Tang, Y. K. (2011). International entrepreneurship research (1989-2009): a domain ontology and thematic analysis. Journal of business venturing, 26(6), 632-659. https://doi.org/10.1016/j.jbusvent.2011.04.001

Knight, F. H. (1921). Risk, uncertainty and profit. New York: Hart, Schaffner and Marx.

Mainela, T., Puhakka, V., \& Servais, P. (2014). The concept of international opportunity in international entrepreneurship: a review and a research agenda. International Journal of Management Reviews, 16(1), 105-129. https://doi.org/10.1111/ijmr.12011

Mainela, T., Puhakka, V., \& Wakkee, I. (2017). International Opportunities and Value Creation in International Entrepreneurship Value Creation in International Business (pp. 55-80): Springer. https://doi.org/10.1007/978-3-319-39369-8_3

McDougall, P. P., \& Oviatt, B. M. (2000). International entrepreneurship: the intersection of two research paths. Academy of management Journal, 43(5), 902-906.

Muzychenko, O., \& Liesch, P. W. (2015). International opportunity identification in the internationalisation of the firm. Journal of World Business, 50(4), 704-717. https://doi.org/10.1016/j.jwb.2014.12.001

North, D. C. (1990). A transaction cost theory of politics. Journal of Theoretical Politics, 2(4), $355-367$. https://doi.org/10.1177/0951692890002004001 
Oviatt, B. M., \& McDougall, P. P. (2005). Defining international entrepreneurship and modeling the speed of internationalization. Entrepreneurship theory and practice, 29(5), 537-554. https://doi.org/10.1111/j.1540-6520.2005.00097.x

Peiris, I. K. (2014). Entrepreneurial Dynamics of Internationalising Ventures: The Opportunity-Value Creation Nexus. University of Waikato.

Peiris, I. K., Akoorie, M., \& Sinha, P. (2015). Conceptualizing the Process of Opportunity Identification in International Entrepreneurship Research. In M. J. Manimala \& K. P. Wasdani (Eds.), Entrepreneurial Ecosystem: Perspectives from Emerging Economies (pp. 193-218). New Delhi: Springer India. https://doi.org/10.1007/978-81-322-2086-2_8

Peiris, I. K., Akoorie, M., \& Sinha, P. (2015). Conceptualizing the process of opportunity identification in international entrepreneurship research Entrepreneurial Ecosystem (pp. 193-218): Springer.

Peng, M. W., \& Delios, A. (2006). What determines the scope of the firm over time and around the world? An Asia Pacific perspective: Springer.

Petti, C. (2009). Cases in technological entrepreneurship: Converting ideas into value: Edward Elgar Publishing. https://doi.org/10.4337/9781848449312

Petti, C., \& Zhang, S. (2011). Explaining technological innovation in Chinese enterprises: Insights from technological entrepreneurship. Frontiers of Business Research in China, 5(3), 452. https://doi.org/10.1007/s11782-011-0140-5

Prahalad, C. K., \& Hamel, G. (2000). The core competence of the corporation Strategic learning in a knowledge economy (pp. 3-22): Elsevier.

Ratinho, T., Harms, R., \& Walsh, S. (2015). Structuring the Technology Entrepreneurship publication landscape: Making sense out of chaos. Technological forecasting and social change, 100, 168-175. https://doi.org/10.1016/j.techfore.2015.05.004

Sarasvathy, S. (2008). Effectuation: Elements of entrepreneurial orientation: Edward Elgar Publishing, Cheltenham, UK. https://doi.org/10.4337/9781848440197

Sarasvathy, S. D. (2001). Causation and effectuation: Toward a theoretical shift from economic inevitability to entrepreneurial contingency. Academy of management review, 26(2), 243-263. https://doi.org/10.5465/amr.2001.4378020

Schumpeter, J. A. (1934). Change and the Entrepreneur. Essays of JA Schumpeter.

Spiegel, M., \& Marxt, C. (2011). Defining Technology Entrepreneurship. Paper presented at the Industrial Engineering and Engineering Management (IEEM), 2011 IEEE International Conference on. https://doi.org/10.1109/IEEM.2011.6118191

Tripathi, S. S., \& Brahma, M. (2018). Technology Entrepreneurship in Emerging Markets: An Exploration of Entrepreneurial Models Prevalent in India. Technology Innovation Management Review, 8(1), 24. https://doi.org/10.22215/timreview/1131

Walsh, S. T., \& Linton, J. D. (2011). The strategy-technology firm fit audit: a guide to opportunity assessment and selection. Technological forecasting and social change, 78(2), 199-216. https://doi.org/10.1016/j.techfore.2010.06.023

Wernerfelt, B. (2011). Invited editorial: The use of resources in resource acquisition. Journal of management, 37(5), 1369-1373. https://doi.org/10.1177/0149206310371693

Williamson, O. E. (2005). Transaction cost economics and business administration. Scandinavian Journal of Management, 2l(1), 19-40. https://doi.org/10.1016/j.scaman.2005.02.002

Zahra, S. A., Korri, J. S., \& Yu, J. (2005). Cognition and international entrepreneurship: implications for research on international opportunity recognition and exploitation. International business review, 14(2), 129-146. https://doi.org/10.1016/j.ibusrev.2004.04.005

\section{Copyrights}

Copyright for this article is retained by the author(s), with first publication rights granted to the journal.

This is an open-access article distributed under the terms and conditions of the Creative Commons Attribution license (http://creativecommons.org/licenses/by/4.0/). 